\title{
Cellular senescence in ionizing radiation (Review)
}

\author{
ZHENGTING CHEN ${ }^{1,2^{*}}, \mathrm{KE} \mathrm{CAO}^{1,2^{*}}$, YAOXIONG XIA $^{1 *}$, YUNFEN LI $^{1 *}, \mathrm{YU} \mathrm{HOU}^{1}$, \\ LI WANG $^{1}$, LAN LI ${ }^{1}$, LI CHANG ${ }^{1}$ and WENHUI LI ${ }^{1}$
}

\begin{abstract}
${ }^{1}$ Department of Radiation Oncology, The Third Affiliated Hospital of Kunming Medical University/Yunnan Cancer Hospital;
${ }^{2}$ Key Laboratory of Lung Cancer Research of Yunnan Province, The Third Affiliated Hospital of Kunming Medical University/ Yunnan Cancer Center, Kunming, Yunnan 650118, P.R. China
\end{abstract}

Received February 25, 2019; Accepted June 18, 2019

DOI: 10.3892/or.2019.7209

\begin{abstract}
Radiotherapy (RT) is one of most common treatments for cancer. However, overcoming the failure and side effects of RT as well as radioresistance, recurrence and metastasis remains challenging in cancer treatment. Cellular senescence (CS) is permanent arrested state of cell division induced by various factors, including exposure to ionizing radiation (IR). CS induced by IR contributes to tumour cell control and often even causes side effects in normal cells. Improvement of the therapeutic RT ratio is dependent on more cancer cell death and less normal cell damage. In addition, the biological behaviour of tumour cells after IR has also been linked to CS. This review summarizes our understanding of CS in IR, which may be beneficial for providing new insight for improving the therapeutic outcomes of RT.
\end{abstract}

Correspondence to: Professor Wenhui Li or Professor Li Chang, Department of Radiation Oncology, The Third Affiliated Hospital of Kunming Medical University/Yunnan Cancer Hospital, Yunnan Cancer Hospital, 519 Kunzhou Road, Kunming, Yunnan 650118, P.R. China

E-mail: wenhuili64@yeah.net

E-mail: changli1981@126.com

*Contributed equally

Abbreviations: BM, bone marrow; BSE, bystander effect; CICs, cancer initiating cells; CS, cellular senescence; CSCs, cancer stem cells; DDR, DNA damage response; DSBs, DNA double-strand breaks; ECs, endothelial cells; EMT, epithelial-mesenchymal transition; HUVECs, human umbilical vein endothelial cells; IR, ionizing radiation; IRIS, IR-induced cellular senescence; MMPs, matrix metalloproteinases; Rb, retinoblastoma; MAPK, mitogen-activated protein kinase; MSCs, mesenchymal stem cells; PARP(i), poly(ADP-ribose) polymerase (inhibitor); SA- $\beta-G a l$, senescence-associated $\beta$-galactosidase; SASP, senescence-associated secretory phenotype; SIPS, stress-induced premature senescence; SLGA, senescence-like growth arrest; SNCs, senescent cells; TBI, total body irradiation; PF, pulmonary fibrosis

Key words: ionizing radiation, senescence-associated secretory phenotype, radiosensitivity, epithelial-mesenchymal transition, cellular senescence

\section{Contents}

\author{
1. Introduction \\ 2. IR-induced CS \\ 3. CS and radiosensitivity \\ 4. CS and IR side effects \\ 5. IRIS and tumour cell biological behaviour \\ 6. Other related mechanisms \\ 7. Future perspectives
}

\section{Introduction}

Senescence has been identified for decades (1), and cellular senescence (CS) represents a relatively stable state of proliferative arrest accompanied by failure to re-enter the cell division cycle. Generally, CS is divided into replicative CS resulting from telomere shortening and premature CS that is induced by various types of stress. Due to the increasing evidence of linkages between senescent cells (SNCs) and many age-related diseases, including cancer, atherosclerosis, osteoarthritis, and neurodegenerative diseases (2-5), methods for eradicating SNCs are a hot topic in research on these diseases (6). However, CS appears to play dual roles in cancer radiotherapy (RT). On the one hand, CS induced by ionizing radiation (IR), a major type of RT, can inhibit the proliferation of tumour cells and activate cancer immune surveillance. Many radiosensitizers are aimed at increasing CS when combined with IR $(7,8)$. On the other hand, IR can induce senescence in surrounding and normal cells as well as in cancer cells, which leads to normal tissue fibrosis and organ dysfunction (9). Moreover, IR-induced CS (IRIS) may emerge as a method for helping cancer cells overcome RT and worsen the biological behaviour of tumour cells following IR treatment $(10,11)$.

The aim of this review was to focus on CS in IR by evaluating radiosensitivity, IR-induced side effects, tumour cell biological behavioural changes after IRIS and underlying mechanisms. It was hypothesized that a comprehensive understanding may provide new insights into novel therapeutic modalities in RT to improve the outcomes of cancer patients.

\section{IR-induced CS}

IR kills tumour cells by causing lethal DNA damage, which can ignite the DNA damage response (DDR), and non-homologous 
end joining (NHEJ) and homologous recombination (HR) are the two main pathways for repairing double-strand breaks (DSBs) induced by DNA damage. The accuracy of DNA damage repair by related downstream signalling pathways determines cell fate, including senescence and apoptosis (12). Generally, DNA DSBs are an especially potent stimulus for inducing CS (13). IRIS, is also a form of stress-induced premature senescence (SIPS) (14) and can occur in many types of cells, including cancer cells, fibroblasts, epithelial cells, endothelial cells (ECs), immune cells, and stem cells. Senescent cells (SCNs) always exhibit apoptosis resistance, metabolic activity, proinflammatory and profibrotic molecule secretion and neighbouring microenvironment alteration despite that they have no cell division capacity and permanently arrested proliferation (15) (Fig. 1).

Cell division cycle arrest. In the senescence process induced by IR, the cell cycle is interrupted by G2 arrest after inevitable DNA damage, accompanied by mitotic bypass into the G1 phase (16). Ataxia telangiectasia-mutated protein (ATM), $\mathrm{p} 53, \mathrm{p} 21, \mathrm{p} 16-\mathrm{Rb}, \mathrm{p} 38-\mathrm{mitogen}$-activated protein kinase (p38-MAPK), NF- $\mathrm{KB}$ signalling pathway factors, reactive oxygen species (ROS), senescence-associated secretory phenotype (SASP) factors and cyclin-CDK complexes are involved in this process $(9,16,17)$. Different doses of IR and DNA damage can lead to various types of cells with mitotic cell cycle delays, including arrests in the G1, G2 or S phase. G2 arrest and G2 slippage has been linked to IRIS in most previous studies and reviews (18-21). SNCs can be identified by prominent $\beta$-galactosidase activity, increased $\mathrm{p} 53, \mathrm{p} 21$ and p16 expression, and decreased levels of Cdc2 and survivin. Notably, some features of IRIS in normal cells and cancer cells are summarized in Table I.

p53. The function of the tumour suppressor protein $\mathrm{p} 53$ is related to cell cycle control, DNA repair and apoptosis (40). p53 and phosphorylated retinoblastoma protein (pRB) are the main proteins involved in establishing and maintaining the state of irreversible growth arrest in replicative senescence in normal human cells, and p53 inactivation could reverse CS in BJ cells with a low level of p16 (41). Many studies (42-45) have been carried out to explore the influence of p53 on IR-induced effects. For example, HCT116 $553^{+/+}$cells were found to be much more susceptible to IRIS than $\mathrm{p} 53^{-/}$cells (43). IR-induced mitotic skipping during senescence-like growth arrest is associated with $\mathrm{p} 53$ function (24). Therefore, the mechanisms of p53, the guardian of the genome, and its related signalling pathways are well characterized in IRIS.

Other proteins/factors related to p53. Increasing evidence supports that insulin-like growth factor-binding protein 5 (IGFBP-5) plays a crucial role in CS via a p53-dependent pathway and especially functions in the coagulation factor Xa- or interleukin-6 (IL-6)-induced premature senescence of ECs, smooth muscle cells (SMCs), and fibroblasts (46-48). Exogenous IGFBP-5 or IGFBP-5 overexpression induces premature senescence in human umbilical vein endothelial cells (HUVECs) in vitro, and knocking down IGFBP-5 can partially alter the senescence process in vitro (48). Notably, IGFBP-5 is upregulated in the IRIS of HUVECs after chronic low-dose IR (49) and may therefore be a significant target to reduce IRIS in normal cells. In addition, the BRE gene (BRCC45) is also associated with the DNA damage-induced premature senescence of fibroblasts resulting from $\gamma$-IR (50). Downregulation of the lamin-B receptor (LBR) and LB1 is a primary response of cells to various stresses leading to senescence, and the loss of LB1 can even serve as a biomarker of senescence $(51,52)$. Naturally, other factors involved in IRIS are independent of p53. For instance, oestrogen E2 suppressed IRIS by inhibiting the binding of cyclin E with $\mathrm{p} 21$ and the functional inactivation of $\mathrm{p} 21$, followed by permanent $\mathrm{Rb}$ hyperphosphorylation, but it did not affect p53 activation in MCF-7 breast cancer cells (53).

lncRNAs and miRNAs. Long non-coding RNAs and microRNAs also contribute to CS induced by IR $(23,54)$. IRIS is modulated by miR-155 via the p53 and p38-MAPK pathways and partially regulates tumour protein 53 -induced nuclear protein 1 (TP53INP1) expression in human WI-38 lung fibroblasts (23). The overexpression of miR-30e in HCT116 cells was revealed to markedly accelerate and augment the $\gamma$-IR-induced caspase-3-like DEVDase senescent phenotype because miR-30e upregulates p21 expression (55). However, miR-30e could not induce senescence in the poorly differentiated RKO colon carcinoma cells (55). This finding demonstrated that miR-30e controls IRIS and may be affected by the differentiation degree of the cell lines.

$I R$ dose and fraction regimen. Other factors also affect the process of IRIS. For example, the IR dose plays a crucial role in inducing senescence or apoptosis upon cell exposure; a low dose (0.5-10 Gy) of IR induces senescence, while a very high dose (>10 Gy) induces apoptosis (30), and this phenomenon is related to the level of DNA damage and function of the DDR network. Recently, Velegzhaninov et al (56) reported that a single low dose (30-50 mGy) of gamma irradiation could suppress CS in normal human fibroblasts. Similarly, a single low-dose X-ray could promote the proliferation of normal cells but not of cancer cells (29). However, low-dose fractionated IR (5x1 Gy) induced temporal patterns of p53/p21 expression in MRC5 fibroblasts, resulting in more significant CS than that generated by a single 5 Gy pulse of IR, as indicated by an integrated stochastic model of DNA damage repair (57). Therefore, the fraction regimen also appears to affect IRIS and may respond differently in different cells. For example, lymphocytic leukaemia cells with exponential growth similar to that of rapidly proliferating tumour cells are not very sensitive to fraction size, while slow-growing fibroblasts and most late-responding cells show high sensitivity (31). Therefore, haematological toxicity occurs early during the RT process, and monitoring and preventing the development of leukopenia is of great importance. Other side effects of IRIS are discussed more specifically in section four.

CSCs. Surviving non-tumourigenic cells were revealed to be more prone to CS, while breast cancer initiating cells (CICs) could be mobilized from the quiescent/G0 phase of the cell cycle to actively cycling cells after sublethal doses of radiation (33). CICs, also called cancer stem cells (CSCs), derived from many types of human cancers and cancer cell lines 


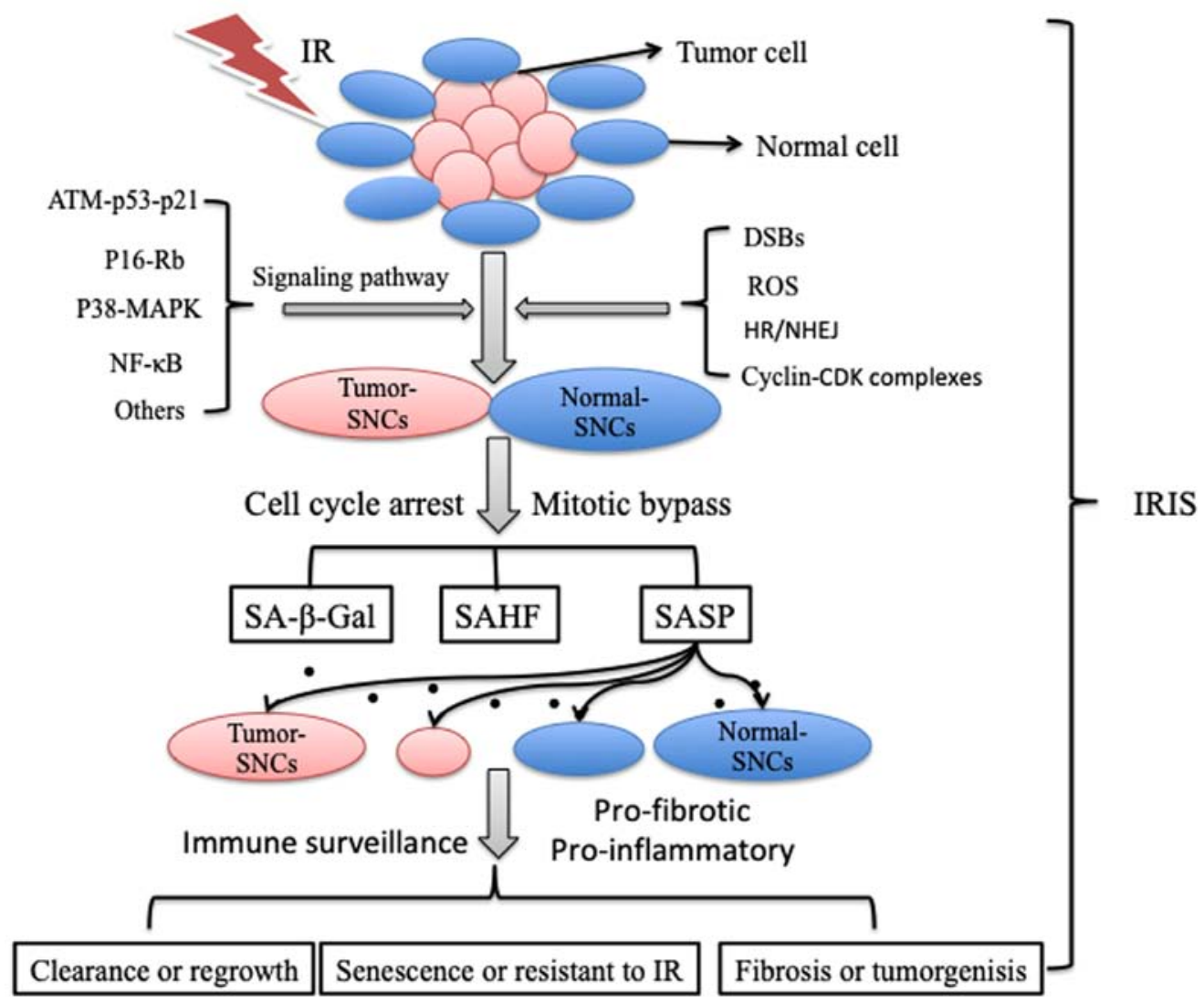

Figure 1. Cellular senescence is induced by IR. The exposure of both tumour cells and normal cells to IR can lead to DNA damage. NHEJ and HR are two main pathways for repairing DSBs, which are especially potent stimuli for inducing CS. Inevitable DNA damage triggers cell cycle arrest accompanied by mitotic bypass. ATM, p53, p21, p16-Rb, p38-MAPK, factors in the NF- $\mathrm{BB}$ signalling pathway, ROS and cyclin-CDK complexes are involved in this process. SNCs demonstrate senescence-associated heterochromatin foci, activated metabolism, the SASP and SA- $\beta$-Gal-positive staining. The SASP contributes to profibrotic and proinflammatory factors and plays a role in active immune surveillance. The SASP also alters tissues and the surrounding microenvironment through paracrine, autocrine, or endocrine methods. Finally, tumour SNCs may be cleared or regrown, and normal SNCs may be obliterated, induce fibrosis or promote tumourgenisis. Furthermore, non-senescent cells may become senescent or resistant to IR. ATM, ataxia telangiectasia mutated protein; CDK, cyclin-dependent kinase; DDR, DNA damage response; DSBs, DNA double-strand breaks; HR, homologous recombination; IR, ionizing radiation; IRIS, IR-induced cellular senescence; NF-кB, nuclear factor $\kappa$-B; NHEJ, non-homologous end joining; p38MAPK, p38 mitogen-activated protein kinase; pRb, retinoblastoma protein; ROS, reactive oxygen species; SA- $\beta$-Gal, senescence-associated $\beta$-galactosidase; SAHF, senescence-associated heterochromatin foci; SASP, senescence-associated secretory phenotype; SNCs, senescent cells; tumor-SNCs, tumour senescent cells; normal-SNCs, normal senescent cells.

demonstrate increased therapeutic resistance, partly because they can evade differentiation and senescence induced by the immune-suppression cytokine interferon (IFN) signalling pathway (58-60).

Studenckan et al (27) coined the term 'senoptosis', which refers to the phenomenon of $\gamma$-IR inducing deep senescence in human diploid fibroblasts (HDFs) with features of both senescence and apoptosis. Senescence-associated CD4 ${ }^{+} \mathrm{T}(\mathrm{SA}-\mathrm{T})$ cells, $\mathrm{PD}-1^{+}$and $\mathrm{CD} 153^{+} \mathrm{CD} 44^{\text {high }}$ cells could serve as suitable biomarkers of immune ageing, as well as potential targets for controlling cancer (61). These observations could lead to new theories for predicting the prognosis of patients after treatment with a combination of immune therapy and RT.

The mechanisms underlying IRIS are becoming increasingly abundant and clear, ranging from the classical cell cycle regulation, DDR and DNA damage repair processes to related miRNAs, IncRNAs, IR factors and cell heterogeneity. Moreover, numerous unelucidated and unsolved problems related to the induction of CS by IR remain, and IRIS appear to be more complex in cancer cells than in normal cells partly because of the intricate biological features of tumour cells.

\section{CS and radiosensitivity}

IRIS is the result of the inaccurate repair of damaged DNA after IR. Targeting accelerated and increased IRIS has been an important method for increasing the effectiveness of RT.

Poly (ADP-ribose) polymerase (PARP) is known to function in various DNA repair mechanisms, such as base excision repair, HR and NHEJ. PARP inhibitor (PARPi) has been used to treat tumours with BRCA1 or BRCA2 mutations (62) and can be used in combination with other treatment measures. Many studies have indicated that PARPis can sensitize most cancer cells to IR by prolonging growth arrest and CS (63-65). Concurrent therapy with blockade of DNA-dependent protein kinase (DNA-PK) and PARP-1 can accelerate the senescence of irradiated non-small cell lung cancer (NSCLC) cells and irradiated $\mathrm{H} 460$ xenografts further than that achieved with IR alone (66) (Table II).

Other evidence has also demonstrated that CS and irradiation have a synergistic effect when applied in combination with irradiation. Phosphorothioate-modified antisense oligonucleotide (PS62ASODN), which inhibits human telomerase reverse transcriptase (hTERT) to stimulate senescence, 
Table I. Features of IRIS in normal cells and cancer cells.

\begin{tabular}{|c|c|c|c|}
\hline Features & Normal senescent cells & Neoplastic senescent cells & (Refs.) \\
\hline $\begin{array}{l}\text { Morphological } \\
\text { transformation }\end{array}$ & \multicolumn{2}{|c|}{$\begin{array}{l}\text { Larger, flattened, increased granularity, and } \\
\text { increased cytoplasmic vacuolar content }\end{array}$} & $(22,23)$ \\
\hline Cell cycle arrest & \multicolumn{2}{|c|}{$\begin{array}{c}\text { a. S and G2/M-phase arrest, mitotic skipping, } \\
\text { overexpression of cyclin D1, tetraploid cells } \\
\text { b. Related to the DDR-network }\end{array}$} & $(24-26)$ \\
\hline Special description & \multicolumn{2}{|c|}{ Senoptosis ${ }^{\text {a }}$ S Senescence-like growth arrest (SLGA) } & $(27,28)$ \\
\hline IR dose dependent & $\begin{array}{l}\text { Low dose resistant to CS, even promote } \\
\text { proliferation }\end{array}$ & From low to high dose can lead to CS & $(29,30)$ \\
\hline Fraction size & $\begin{array}{l}\text { Slow-growing fibroblasts and most } \\
\text { late-responding cells exhibit high sensitivity }\end{array}$ & $\begin{array}{l}\text { a. Rapidly proliferating tumour cells } \\
\text { are not very sensitive } \\
\text { b. Similar: single dose or fractioned } \\
\text { irradiation }\end{array}$ & $(31,32)$ \\
\hline Cell type & Almost all normal cells can develop IRIS & $\begin{array}{l}\text { a. non-tumorigenic cells more prone } \\
\text { than CSCs } \\
\text { b. degree of differentiation }\end{array}$ & $(33-35)$ \\
\hline SASP & $\begin{array}{l}\text { A range of pro- inflammatory and pro-fibrotic } \\
\text { chemokines, cytokines, growth factors and } \\
\text { proteases, such as IL- } 1 \text {, IL- } 6 / 8, \text { CXCL1, } \\
\text { CCL2, MMPs, TGF- } \beta \text {, HGF, GM-CSF }\end{array}$ & $\begin{array}{l}\text { Differ among different cells, high } \\
\text { heterogeneity }\end{array}$ & $(34,36)$ \\
\hline Bystander effect & $\begin{array}{l}\text { Especially in senescent fibroblasts and } \\
\text { senescent ECs }\end{array}$ & $\begin{array}{l}\text { Breast cancer cells, CRC cells, } \\
\text { NSCLC cells }\end{array}$ & $(37-39)$ \\
\hline
\end{tabular}

enhanced the inhibition of tumour characteristics in liver cancer cells (67). Telomeric repeat-binding factor 2 (TRF2), a member of the shelterin complex that plays a key role in protecting and stabilizing chromosomal ends, markedly increased the radiosensitivity of human mesenchymal stem cells (hMSCs) compared to that of controls in both proliferation and senescence assays (68). Similarly, inhibition of the mammalian target of rapamycin (MTOR) pathway can augment the radiosensitivity of cancer cells by promoting CS (69). In glioblastoma (GBM) cells, silencing both histone deacetylase 4 (HDAC4) and erythropoietin receptor (EPOR) promoted IR-induced senescence and reversed radioresistance (70-71). Moreover, GBM cells treated with verapamil in combination with carmustine and irradiation were more vulnerable to IRIS than those subjected to individual or dual-combination treatment (72).

Irradiated non-small cell lung cancer (NSCLC) cells can be rendered more radiosensitive by inhibiting epidermal growth factor receptor (EGFR) in a p53-dependent senescence pathway (73). However, other evidence has revealed that senescence is a prominent mechanism of radiosensitization in $45 \%$ of NSCLC cell lines and occurs independent of the p53 status but is linked to p16 induction. Senescence and radiosensitization have also been linked to an increase in residual radiation-induced DNA damage, especially DSBs, regardless of the p53/p16 status (73). Notably, irrespective of the cell-based assay employed, caution should be paid to avoid misinterpreting radiosensitivity data in terms of reduced viability (74). Furthermore, similar to receptor tyrosine kinase (RTK) targeting strategies in cancer, IRIS could represent a potential alternative treatment outcome, both allowing tumour growth control and enabling patients to have a better quality of life (75). However, as the SASP incidence increases, IRIS appears to be a candidate mechanism contributing to Fanconi anaemia complementation group A (FancA)-mediated radioresistance in head and neck squamous cell carcinoma (11).

Collectively, these findings indicate that many radiosensitizers function based on CS. Limited benefits suggest that more complicated mechanisms should be considered and explored because CS may facilitate radioresistance in tumour cells and increase the radiosensitivity of surrounding normal cells.

\section{CS and IR side effects}

CS induced by IR in normal cells leads to tissue fibrosis and organ dysfunction and increases the risk of secondary neoplasms in almost all bodily systems $(42,64)$. As a result, decreasing these side effects induced by IRIS has been a 
Table II. CS and radiosensitivity in typical types of cancer cells.

\begin{tabular}{|c|c|c|c|c|}
\hline Type of cancer (cells) & Gene/medicine & Mechanisms/Targets & $\begin{array}{l}\text { Role of CS } \\
\text { (Se- or Re-) }\end{array}$ & (Refs.) \\
\hline HNSCC & FancA & SASP & Re- & (11) \\
\hline NSCLC (H460 and A549) & PAPRi+ inhibitors of DNA-PK & Promoting G2-M cell cycle arrest & $\mathrm{Se}$ & $(66)$ \\
\hline Liver cancer (Walker 256) & PS62ASODN & Against hTERT & Se- & $(67)$ \\
\hline hMSC & TRF2 & $\begin{array}{l}\text { Protecting and stabilizing } \\
\text { chromosomal ends }\end{array}$ & Se- & $(68)$ \\
\hline GBM (U251MG, U87MG) & HDAC4 silencing & Sustain Double strand break repair & Se- & $(70)$ \\
\hline GBM (U87MG) & Verapamil+carmustine & $\begin{array}{l}\text { Reducing intra-cellular ROS } \\
\text { and calcium ion levels }\end{array}$ & Se- & $(72)$ \\
\hline GBM cells & EPOR silencing & Inducing $\mathrm{G} 2 / \mathrm{M}$ cell cycle arrest & Se- & $(71)$ \\
\hline $\begin{array}{l}\text { Breast cancer cells } \\
\text { (MCF-7 cells) }\end{array}$ & Telomere-mitochondrion link & $\begin{array}{l}\text { Telomere dysfunction hTERT } \\
\text { suppression }\end{array}$ & Se- & (76) \\
\hline Sarcoma cells & HSP90 & Inducing CS & Se- & (77) \\
\hline
\end{tabular}

direction for improving the therapeutic radiation ratio with the exception of radiosensitizers. An increasing number of researchers are exploring the deeper mechanisms underlying this process, and some interference targets have exhibited potential to suppress CS in normal cells (Table III).

Telomeres. The length of telomeres in somatic cells shortens over time due to increasing age or pathogenic factors, resulting in CS. Both chemotherapy and RT significantly impair telomere maintenance and function in normal human cells, which may lead to CS and ultimately result in tissue/organ damage and secondary malignancies in long-term survivors of cancer (78). However, the telomere length and the telomere length distribution in peripheral leukocytes was revealed to remain unchanged after RT (79). Residual NP-2 cells (human glioma-derived cells) exhibited CS without changes in telomere length after 6 Gy of C-ion irradiation (80).

Pulmonary fibrosis. IR-induced pulmonary fibrosis (PF) is a severe late side effect of thoracic RT. Irradiated mice administered with an inhibitor of B-cell lymphoma-2 (Bcl-2)/B-cell lymphoma-extra large (BCL-xL) via gavage after persistent $\mathrm{PF}$ developed reduced type II pneumocyte senescence, and PF was reversed (81). Both recombinant truncated plasminogen activator inhibitor-1 (PAI-1) protein (rPAI-1) and rapamycin, were revealed to prevent radiation-induced fibrosis in the lungs of mice $(82,83)$. In terms of CS, these data indicate that $\mathrm{PF}$ is less challenging to treat and more preventable than ever.

Myelosuppression. Total body irradiation (TBI) induces long-term bone marrow (BM) suppression via the induction of premature senescence in haematopoietic stem cells (HSCs) in a p16-independent manner (84). The selective clearance of
SCNs, including senescent BM-derived HSCs and senescent muscle stem cells, by a pharmacological agent or small-molecule inhibitor of p38 MAPK was beneficial in part through its rejuvenation of aged tissue stem cells and rescue of long-term myelosuppression $(85,86)$.

Childhood cancer survivors. Childhood cancer survivors are at an increased risk of frailty, which is partly a result of RT (87); however, IR-reduced CS in children has more profound influences. The leukocyte telomere length (LTL) was shorter in childhood acute lymphocytic leukaemia (ALL) survivors who underwent treatment with cranial IR than in survivors in the control group, which may lead to the premature development of age-related chronic conditions in survivors (88). Notably, a regeneration defect in ageing germline stem cells after IR could be treated by the loss of FOXO in an adult model of stem cell injury induced by low-dose IR (89).

$R B$ gene and other key genes. These researchers also justified that MSCs in which members of the RB gene family were silenced did not exhibit increased apoptosis, necrosis or senescence compared with untreated cells after exposure to X-rays at 40 and 2,000 $\mathrm{mGy}$. These surviving MSCs exhibited accumulated DNA damage and may have undergone neoplastic transformation (90). Therefore, attention should be paid to cancer patients with RB gene mutations in terms of evaluating the onset of secondary neoplasms following RT. Another research group used weighted gene co-expression network analysis (WGCNA) to screen for differentially expressed genes between the senescence and non-senescence groups following RT and identified six hub genes: BANK1, Tomm70a, AFAP1, Cd84, Nuf2 and NFE2 (91). The authors provided an alternate method to search for key genes linked to IRIS and built a foundation for exploring these genes (91). 
Table III. Cellular senescence and IR side effects.

\begin{tabular}{|c|c|c|c|c|c|}
\hline Side effect & Irradiation & Experimental cell/animal & Targets & Method & (Refs.) \\
\hline $\begin{array}{l}\text { Premature } \\
\text { neurodegenerative } \\
\text { diseases }\end{array}$ & Single $20 \mathrm{~Gy}$ & $\begin{array}{l}\text { Brain microvascular } \\
\text { endothelial cells } \\
\text { (bEnd. } 3 \text { cells) }\end{array}$ & $\begin{array}{l}\text { A Disintegrin And } \\
\text { Metalloprotease } 10 \\
\text { (ADAM10) }\end{array}$ & $\begin{array}{l}\text { Downregulation } \\
\text { of ADAM } 10\end{array}$ & (4) \\
\hline $\begin{array}{l}\text { Hippocampus } \\
\text { damage }\end{array}$ & $\begin{array}{l}5 \text { Gy of cranial } \\
\text { IR }\end{array}$ & $\begin{array}{l}\text { Whole-brain irradiation } \\
\text { mouse }\end{array}$ & $\begin{array}{l}\mathrm{p} 53, \mathrm{p} 21, \text { and IL-6 } \\
\text { were increased }\end{array}$ & $\begin{array}{l}\text { Knockout of the } \\
\text { TRP53 or p } 21 \text { gene }\end{array}$ & $(42)$ \\
\hline $\begin{array}{l}\text { Neuropsychological } \\
\text { deficits }\end{array}$ & $\mathrm{X}$-rays & $\begin{array}{l}\text { Neural stem and } \\
\text { progenitor cells (NSPCs) }\end{array}$ & Caspase- 1 activation & - & $(65)$ \\
\hline $\mathrm{PF}$ & 17 Gy X-ray & $\begin{array}{l}\text { C57BL/6J mice, } \\
\text { type } 2 \text { pneumocytes }\end{array}$ & MMP-3, IL-1, TGF- $\beta$ & $\begin{array}{l}\text { Inhibitor of Bcl-2/ } \\
\text { BCL-xL; rPAI-1; } \\
\text { Rapamycin }\end{array}$ & $(81-83)$ \\
\hline $\begin{array}{l}\text { Adult stem cell } \\
\text { injury }\end{array}$ & $50 \mathrm{~Gy}$ & $\begin{array}{l}\text { Drosophila melanogaster } \\
\text { (GSCs) }\end{array}$ & $\begin{array}{l}\text { FOXO and mTOR } \\
\text { homologue }\end{array}$ & FOXO RNAi & (89) \\
\hline $\begin{array}{l}\text { IR-induced DNA } \\
\text { damage }\end{array}$ & $\begin{array}{l}2.5 \mathrm{~Gy} \text { and } \\
10 \mathrm{~Gy} \gamma \text {-IR }\end{array}$ & $\begin{array}{l}\text { Human breast cancer } \\
\text { and fibroblasts }\end{array}$ & $\begin{array}{l}\text { Different responses to } \\
\text { LLLT following } \\
\text { exposure to IR }\end{array}$ & LLLT & (93) \\
\hline $\begin{array}{l}\text { Radiation-induced } \\
\text { collagen contraction }\end{array}$ & 2 Gy & $\begin{array}{l}\text { fibroblasts, } \\
\text { CRC cells }\end{array}$ & $\begin{array}{l}\text { Fibroblasts and CRC } \\
\text { cells present different } \\
\text { responses to medicine }\end{array}$ & $\begin{array}{l}\text { Manganese } \\
\text { porphyrins } \\
\text {-MnTnBuOE-2-PyP }\end{array}$ & (96) \\
\hline $\mathrm{PF}$ & $\begin{array}{l}12.5 \text { Gy thorax } \\
\text { irradiation }\end{array}$ & C57BL/6J mice & Pathogenesis (model) & $\begin{array}{l}\text { RNA sequencing } \\
\text { of lung tissue }\end{array}$ & (97) \\
\hline $\begin{array}{l}\text { IR-induced } \\
\text { cardiovascular } \\
\text { disease }\end{array}$ & 10 Gy X-rays & $\begin{array}{l}\text { Human coronary artery } \\
\text { endothelial cells }\end{array}$ & SASP, STAT3, BSE & Proteomics analysis & (98) \\
\hline $\begin{array}{l}\text { IR-Induced damage } \\
\text { in the prostate }\end{array}$ & 2 Gy X-rays & $\begin{array}{l}\text { Mouse prostate fibroblast } \\
\text { cells }\end{array}$ & $\begin{array}{l}\text { TGF- } \beta 1 \text { signaling } \\
\text { pathway }\end{array}$ & $\begin{array}{l}\text { ROS scavenger } \\
\text { (MnTE-2-PyP) }\end{array}$ & (99) \\
\hline $\begin{array}{l}\text { BM suppression, } \\
\text { HSC }\end{array}$ & 6.5 Gy of-IR & Mouse model & ROS-p16 pathway & MnTE & $(100)$ \\
\hline BM injury & 4 Gy $\gamma$-TBI & Ly5.2 mice & Inhibit HSC senescence & Metformin & $(101)$ \\
\hline
\end{tabular}

Bcl-2/BCL-xL, B-cell lymphoma 2/B-cell lymphoma-extra large; BM, bow marrow; BSE, bystander effect; FOXO, Forkhead box O; CRC, colorectal cancer; GSCs, germline stem cells; mTOR, mammalian target of rapamycin; HSC, hematopoietic stem cell; MMP-3, matrix metalloproteinase-3; MnTE, Mn(III) meso-tetrakis-(N-ethylpyridinium-2-yl) porphyrin; IR, ionizing radiation; LLLT, low-level laser therapy; PAI-1, plasminogen activator inhibitor-1; PF, pulmonary fibrosis; Ref. reference; RNAi, RNA interference; ROS, reactive oxygen species; TBI, total body irradiation; TGF- $\beta$, transforming growth factor- $\beta$; SASP, senescence-associated secretory phenotype; STAT3, signal transducer and activator of transcription 3 .

Radiation sources. Different radiation sources used in IR have different effects on normal cells. Alessio et al (92) revealed that IR with $\alpha$ particles created less apoptosis and senescence in BM-MSCs; that is, $\alpha$ particles may spare healthy stem cells more efficaciously than X-rays. Low-level laser therapy (LLLT) enhanced viability and proliferation and reduced senescence of fibroblasts following $\gamma$-IR exposure, while LLLT resulted in decreased proliferation and increased senescence in breast cancer cells (MDA-MB-231 cells) (93). It is worth mentioning that the greater biological efficacy of $\mathrm{C}$ ions compared to that of low linear energy transfer (LET) radiation (X-rays) may be misevaluated in 2D culture experiments (94). Relevant models and beams are necessary to promote the use of charged particles with increased patient safety.

The application of senolytic agents that selectively kill senescent cells may improve organ function, including SNCs induced by IR $(81,95)$. Other therapeutic methods, including antioxidants, free radical scavengers, mTOR inhibitors, anti-inflammatory agents, stem cell therapy and senomorphics, also have the potential to reduce side effects induced by IRIS (9). MnTnBuOE-2-PyP could inhibit radiation-induced collagen contraction and $\mathrm{CS}$ in fibroblasts but could not protect colorectal cancer cells from IR damage $(93,96)$, potentially providing new options for reducing IR-induced damage. However, further investigations need to be performed in humans to evaluate their safety and efficacy.

\section{IRIS and tumour cell biological behaviour}

In fact, the SLGA response to IR may reflect a key mechanism of residual-cell survival, ultimately resulting in radioresistance, tumour regrowth and dormant tumour recurrence (102). Recently, the phenomenon that SCNs can regrow after exposure to IR has attracted increasing attention, which reflects that CS plays 'opposing roles' in RT and other genotoxic therapies $(23,103,104)$. SNCs appearing in the context of 


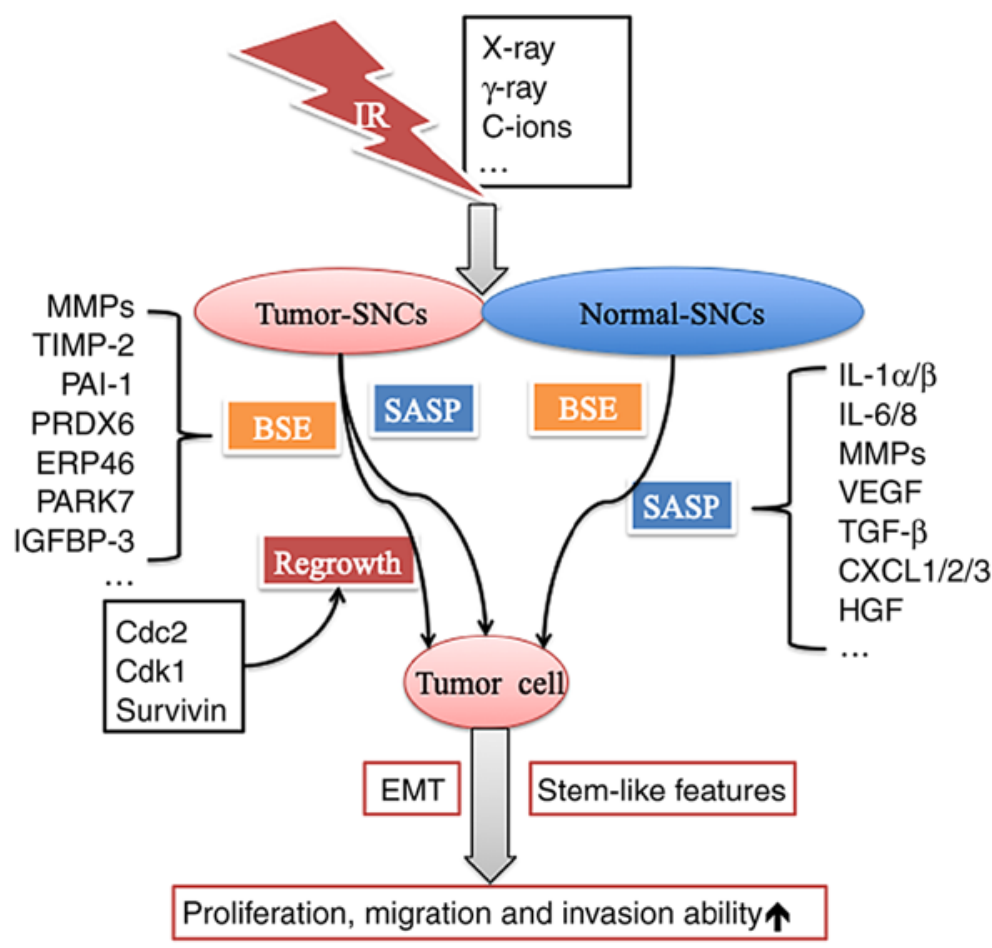

Figure 2. IRIS and biological characteristics of tumour cells. On the one hand, SCNs, including tumor-SNCs and normal-SNCs acquire the ability to secrete many types of factors (e.g., SASP factors: IL-1 $\alpha / \beta$, IL-6/8, MMPs, VEGF, TGF- $\beta$, CXCL1/2/3 and HGF) and facilitate tumour cell growth and invasion in vitro and in vivo. On the other hand, the cells regrown after IRIS may also develop EMT and stem-like features with enhanced proliferation, invasion and migration capacities, than those existing before IR. Upregulation of survivin, Cdc2, and Cdk1 may help senescent tumour cell regrowth. In addition, the IR-induced BSE may have important implications in this progression, and MMPs, TIMP-2, PAI-1, ERP46, PARK7, may participate in this process. BSE, bystander effect; Cdc2, cell division cycle 2; Cdk1, cyclin-dependent kinases; CXCL1/2/3, the chemokine (C-X-C motif) ligand 1/2/3; EMT, epithelial-mesenchymal transition; ERP46, endoplasmic reticulum protein 46; HGF, hepatocyte growth factor; IL-1 $\alpha / \beta / 6 / 8$, interleukin- $1 \alpha / \beta / 6 / 8$; IR, ionizing radiation; IGFBP-3/5, insulin-like growth factor-binding protein-3/5; IRIS, IR-induced cellular senescence; MMPs, matrix metalloproteinases; PAI-1, plasminogen activator inhibitor 1; PARK7, Parkinsonism-associated deglycase; SASP, senescence-associated secretory phenotype; SNCs, senescent cells; TIMP-2, tissue inhibitor of metalloproteinase 2; VEGF, vascular endothelial growth factor; tumor-SNCs, tumour senescent cells; normal-SNCs, normal senescent cells.

neoadjuvant chemoradiotherapy for rectal cancer can promote epithelial-mesenchymal transition (EMT) and further affect the residual tumour microenvironment (105).

Some DNA damage foci induced by IR may persist for a long time. However, the repair of DSBs in SCNs may ultimately result in recovery and regrowth after combination IR/PARPi treatment $(106,107)$. Furthermore, the cells regrown after IRIS may exhibit more aggressive biological behaviours, such as enhanced proliferative ability and increased invasion and migration capacities, than those existing before IR. SCNs also acquired the ability to secrete many types of factors to facilitate growth and invasion in vitro and in vivo (5) (Fig. 2).

Normal cells are more sensitive to the IR dose regarding the changes in proliferative ability induced by IRIS, while tumour cells seem to dull to the IR dose and segmentation mode. Fractionated radiation and single IR (e.g., 6 or $3 \times 2$, 12 or $6 \times 2$ Gy) exposures have equivalent abilities to inhibit tumour growth via IRIS in vitro and in vivo (32). Ablative doses (18 Gy) of radiation exhibit more inhibitory effects on the proliferative, migratory and invasive capacities of lung cancer-associated fibroblasts (CAFs) because CAFs play significant roles in cancer cell invasion and metastasis (108). A low dose of $30 \mathrm{mGy} \gamma$-IR was revealed to increase the overall proliferative potential of normal human fibroblasts (HELF-104) (56), while $\gamma$-IR could inhibit the growth of primary prostate epithelial cells by inducing senescence, not apoptosis (109).

Apart from proliferative arrest, the SASP is another prominent feature of senescent cells (110). The SASP includes cytokines, chemokines, growth factors and proteases and can trigger the activation of a complex signalling network (111). Irradiated ECs may adversely affect non-irradiated surrounding cells via the SASP, which has been linked to radiation-induced cardiovascular disease (98). The cytokine IL-6, an SASP component, is highly upregulated in many cancers and is considered one of the most important cytokines involved in pro- and anti-tumourigenic effects (112). Senescence-associated IL- 6 and IL- 8 cytokines can be triggered by paracrines, autocrines, and endocrines, which reinforce the senescent milieu and inflammatory microenvironment in breast cancer cells (36).

Furthermore, the IR-induced bystander effect (BSE) may have important implications in RT (113). The IR-induced BSE describes how cells not exposed to IR show biological changes under the influence of molecular signals secreted by irradiated neighbouring cells $(113,114)$. Several pathways are involved in the paracrine circuit that induces senescence in neighbouring cells, such as the matrix metalloproteinase-2 (MMP-2)/tissue inhibitor of metalloproteinase-2 (TIMP-2), IGFBP3/PAI-1, and peroxiredoxin 6/endoplasmic reticulum protein 46 (ERP46)/Parkinsonism-associateddeglycase(PARK7)/cathepsin 
D/major vault protein pathways (115). Moreover, lung fibroblasts with premature senescence resulting from IR may strongly enhance the growth of malignant human lung cancer cells (A549 and H1299) in vitro and in immunocompromised mice through increasing the expression of matrix MMPs (38).

In other words, it is common that various tumour cells can undergo SLGA after different types of IR. However, these tumour SNCs may recover their proliferative ability and exhibit more aggressive biological behaviour when the environment is suitable. While the SASP exhibited by tumour SCNs and normal SCNs is mostly responsible for this process, the BSE induced by IR also plays a crucial role via various pathways. However, the complexity of the SASP and various mechanisms of action still restrict our understanding of IRIS (35). The mechanism underlying IR-induced BSE and tumour cell escape from IRIS remains unknown, and further research is urgently required to solve this problem.

\section{Other related mechanisms}

Although the p16-pRB and p53-p21 tumour suppressor pathways are widely recognized as the main mechanisms underlying SLGA, it is still unclear what makes this arrest stable and what makes CS act as a double-edged sword in cancer treatment (116), especially in terms of improving the efficacy of RT. There may be other related mechanisms contributing to IR-induced senescence.

Mitochondrial dysfunction. Mitochondria play an important role in radiation-induced cellular damage, and different qualities of radiation affect the changes in mitochondrial dynamics (117). Cells exposed to low-dose X-rays and replicative senescent cells exhibit a residual capacity to use fatty acids and glutamine as alternative fuels, respectively (118). Several mitochondrial signalling pathways have been revealed to induce CS (119). DNA cleavage occurring in senescent HDFs after $\gamma$-irradiation was triggered by a modest decrease in the mitochondrial membrane potential, which was strong enough to release mitochondrial endonuclease $G$ (EndoG). Then, EndoG translocated into the nucleus to induce the nonlethal cleavage of damaged DNA (27).

IR-induced senescence in quiescent ECs is mediated by at least 2 different pathways dependent on the mitochondrial oxidative stress response and p53 activation (120). hTERT suppression caused by either C ion irradiation or MST-312 impairs mitochondrial function, and telomere-mitochondrion links play a role in the induction of senescence in MCF-7 cells after $\mathrm{C}$ ion irradiation (76).

Ferritinophagy. Ferroptosis is a form of regulated necrotic cell death controlled by glutathione peroxidase 4 (GPX4). Ferritinophagy is a lysosomal process that promotes ferritin degradation and ferroptosis. Iron accumulation in SNCs is driven by impaired ferritinophagy. The autophagy activator rapamycin could prevent both the iron accumulation phenotype of SNCs and the increase in TfR1, ferritin and intracellular iron, however, rapamycin failed to re-sensitize these cells to ferroptosis (121).

Acyl-CoA synthetase long-chain family member 4 (Acsl4) is preferentially expressed in a panel of basal-like breast cancer cell lines and predicts their sensitivity to ferroptosis. Acs14 inhibition is a viable therapeutic approach for preventing ferroptosis-related diseases (122).

Cyclic guanosine monophosphate (GMP)-adenosine monophosphate (AMP) synthase (cGAS). cGAS is a DNA sensor in the DDR process. Genomic DNA damage leads to cGAS activation, stimulation of inflammatory responses, $\mathrm{CS}$ and cancer via the cGAMP/stimulator of interferon genes (STING) pathway (123). cGAS deletion also abrogated SASPs induced by IR. cGAS mediated CS and inhibited immortalization, and cGAS activated antitumour immunity (124). cGAS recognized cytosolic chromatin fragments in SNCs. The activation of cGAS, in turn, triggered the production of SASP factors via STING, thereby promoting paracrine senescence (125).

\section{Future perspectives}

Although our understanding of CS in IR is still initial, similar to RT in the treatment of cancer, IRIS functions as a 'double-edged sword' and crucially influences the comprehensive results of RT. First, because the SASPs created by different types of SCNs are highly different, SCNs play a complicated role in the response of cancer to RT via SASPs. Developing effective pharmacological methods, such as senolytic agents, to remove accumulated SNCs or weaken SASP intensity may be a promising method (126). In addition, combining prosenescence therapy with checkpoint immunotherapy may contribute to eradicating cancer cells from the viewpoint of CS (127). Finally, more well-designed preclinical and clinical trials have the potential to facilitate the development of targeted SNC therapy, which will ultimately improve the clinical outcomes of cancer patients subjected to RT.

\section{Acknowledgements}

Not applicable.

\section{Funding}

The present study was supported by the National Natural Science Foundation of China (nos. 81560488, 81660504 and 81860536), the Yunnan Provincial Training Special Funds for High-level Health Technical Personnel (no. H-201624), the Yunnan Health Science Foundation (nos. 2017NS191, 2018NS0065 and 2018NS0064), the Doctoral Scholar Newcomer Award of Yunnan Province and Graduate Student Innovation Fund of Kunming Medical University (2019D015).

\section{Availability of data and materials}

Not applicable.

\section{Authors' contributions}

ZC, LC, YX and WL conceived and designed the study. KC, YL, LW, LL and YH researched the literature. ZC, LC and WL wrote the manuscript. KC, YX and YL performed data analysis and designed the figures. ZC, KC, YX, YL, YH, LW, LL, LC and WL revised and edited the article. All authors read and approved 
the manuscript and agree to be accountable for all aspects of the research in ensuring that the accuracy or integrity of any part of the work are appropriately investigated and resolved.

\section{Ethics approval and consent to participate}

Not applicable.

\section{Patient consent for publication}

Not applicable.

\section{Competing interests}

The authors declare that they have no competing interests.

\section{References}

1. Hayflick L and Moorhead PS: The serial cultivation of human diploid cell strains. Exp Cell Res 25: 585-621, 1961.

2. Sharpless NE and Sherr CJ: Forging a signature of in vivo senescence. Nat Rev Cancer 15: 397-408, 2015.

3. Sulli G, Rommel A, Wang X, Kolar MJ, Puca F, Saghatelian A, Plikus MV, Verma IM and Panda S: Pharmacological activation of REV-ERBs is lethal in cancer and oncogene-induced senescence. Nature 553: 351-355, 2018.

4. McRobb LS, McKay MJ, Gamble JR, Grace M, Moutrie V, Santos ED, Lee VS, Zhao Z, Molloy MP and Stoodley MA: Ionizing radiation reduces ADAM10 expression in brain microvascular endothelial cells undergoing stress-induced senescence. Aging (Albany NY) 9: 1248-1262, 2017

5. Davalos AR, Coppe JP, Campisi J and Desprez PY: Senescent cells as a source of inflammatory factors for tumor progression. Cancer Metastasis Rev 29: 273-283, 2010.

6. Childs BG, Gluscevic M, Baker DJ, Laberge RM, Marquess D, Dananberg J and van Deursen JM: Senescent cells: An emerging target for diseases of ageing. Nat Rev Drug Discov 16: 718-735, 2017.

7. Eriksson D and Stigbrand T: Radiation-induced cell death mechanisms. Tumour Biol 31: 363-372, 2010.

8. Wang Y, Wang Y, Liu S, Liu Y, Xu H, Liang J, Zhu J, Zhang G, Su W, Dong W and Guo Q: Upregulation of EID3 sensitizes breast cancer cells to ionizing radiation-induced cellular senescence. Biomed Pharmacother 107: 606-614, 2018.

9. Nguyen HQ, To NH, Zadigue P, Kerbrat S, De La Taille A, Le Gouvello S and Belkacemi Y: Ionizing radiation-induced cellular senescence promotes tissue fibrosis after radiotherapy. A review. Crit Rev Oncol Hematol 129: 13-26, 2018.

10. Sun Y, Campisi J, Higano C, Beer TM, Porter P, Coleman I, True L and Nelson PS: Treatment-induced damage to the tumor microenvironment promotes prostate cancer therapy resistance through WNT16B. Nat Med 18: 1359-1368, 2012.

11. Hess J, Unger K, Orth M, Schötz U, Schüttrumpf L, Zangen V, Gimenez-Aznar I, Michna A, Schneider L, Stamp R, et al: Genomic amplification of Fanconi anemia complementation group A (FancA) in head and neck squamous cell carcinoma (HNSCC): Cellular mechanisms of radioresistance and clinical relevance. Cancer Lett 386: 87-99, 2017.

12. Noda A, Hirai Y, Hamasaki K, Mitani H, Nakamura N and Kodama Y: Unrepairable DNA double-strand breaks that are generated by ionising radiation determine the fate of normal human cells. J Cell Sci 125: 5280-5287, 2012

13. Rossiello F, Herbig U, Longhese MP, Fumagalli $M$ and d'Adda di Fagagna F: Irreparable telomeric DNA damage and persistent DDR signalling as a shared causative mechanism of cellular senescence and ageing. Curr Opin Genet Dev 26: 89-95, 2014

14. Suzuki M and Boothman DA: Stress-induced premature senescence (SIPS)-influence of SIPS on radiotherapy. J Radiat Res 49: $105-112,2008$.

15. He S and Sharpless NE: Senescence in health and disease. Cell 169: 1000-1011, 2017.

16. Li M, You L, Xue J and Lu Y: Ionizing radiation-induced cellular senescence in normal, non-transformed cells and the involved DNA damage response: A mini review. Front Pharmacol 9: 522, 2018.
17. Nagane M, Kuppusamy ML, An J, Mast JM, Gogna R, Yasui H, Yamamori T, Inanami O and Kuppusamy P: Ataxia-telangiectasia mutated (ATM) kinase regulates eNOS expression and modulates radiosensitivity in endothelial cells exposed to ionizing radiation. Radiat Res 189: 519-528, 2018.

18. Gire V and Dulic V: Senescence from G2 arrest, revisited. Cell Cycle 14: 297-304, 2015.

19. Krenning L, Feringa FM, Shaltiel IA, Van Den Berg J and Medema RH: Transient activation of $\mathrm{p} 53$ in G2 phase is sufficient to induce senescence. Mol Cell 55: 59-72, 2014.

20. Müllers E, Silva Cascales H, Jaiswal H, Saurin AT and Lindqvist A: Nuclear translocation of Cyclin B1 marks the restriction point for terminal cell cycle exit in G2 phase. Cell Cycle 13: 2733-2743, 2014.

21. Ye C, Zhang X, Wan J, Chang L, Hu W, Bing Z, Zhang S, Li J, He J, Wang J and Zhou G: Radiation-induced cellular senescence results from a slippage of long-term $\mathrm{G} 2$ arrested cells into G1 phase. Cell Cycle 12: 1424-1432, 2013.

22. Kuilman T, Michaloglou C, Mooi WJ and Peeper DS: The essence of senescence. Genes Dev 24: 2463-2479, 2010.

23. Wang Y, Scheiber MN, Neumann C, Calin GA and Zhou D: MicroRNA regulation of ionizing radiation-induced premature senescence. Int J Radiat Oncol Biol Phys 81: 839-848, 2011.

24. Suzuki M, Yamauchi M, Oka Y, Suzuki K and Yamashita S: Live-cell imaging visualizes frequent mitotic skipping during senescence-like growth arrest in mammary carcinoma cells exposed to ionizing radiation. Int J Radiat Oncol Biol Phys 83: e241-e250, 2012.

25. Hudson D, Kovalchuk I, Koturbash I, Kolb B, Martin OA and Kovalchuk O: Induction and persistence of radiation-induced DNA damage is more pronounced in young animals than in old animals. Aging (Albany NY) 3: 609-620, 2011.

26. Kim BC, Han NK, Byun HO, Kim SS, Ahn EK, Chu IS, Leem SH, Lee CK and Lee JS: Time-dependently expressed markers and the characterization for premature senescence induced by ionizing radiation in MCF7. Oncol Rep 24: 395-403, 2010.

27. Studencka M and Schaber J: Senoptosis: Non-lethal DNA cleavage as a route to deep senescence. Oncotarget 8: 30656-30671, 2017.

28. Suzuki K, Mori I, Nakayama Y, Miyakoda M, Kodama S and Watanabe M: Radiation-induced senescence-like growth arrest requires TP53 function but not telomere shortening. Radiat Res 155: 248-253, 2001

29. Liang X, Gu J, Yu D, Wang G, Zhou L, Zhang X, Zhao Y, Chen X, Zheng S, Liu Q, et al: Low-dose radiation induces cell proliferation in human embryonic lung fibroblasts but not in lung cancer cells: Importance of ERK1/2 and AKT signaling pathways. Dose-Response 14: 1559325815622174, 2016.

30. Wang Y, Boerma M and Zhou D: Ionizing radiation-induced endothelial cell senescence and cardiovascular diseases. Radiat Res 186: 153-161, 2016.

31. Rezáčová M, Rudolfová G, Tichý A, Bačíková A, Mutná D, Havelek R, Vávrová J, Odrážka K, Lukášová E and Kozubek S: Accumulation of DNA damage and cell death after fractionated irradiation. Radiat Res 175: 708-718, 2011.

32. Kim BC, Yoo HJ, Lee HC, Kang KA, Jung SH, Lee HJ, Lee M, Park S, Ji YH, Lee YS, et al: Evaluation of premature senescence and senescence biomarkers in carcinoma cells and xenograft mice exposed to single or fractionated irradiation. Oncol Rep 31: 2229-2235, 2014.

33. Lagadec C, Vlashi E, Della Donna L, Meng Y, Dekmezian C, Kim K and Pajonk F: Survival and self-renewing capacity of breast cancer initiating cells during fractionated radiation treatment. Breast Cancer Res 12: R13, 2010.

34. Liakou E, Mavrogonatou E, Pratsinis H, Rizou S, Evangelou K, Panagiotou PN, Karamanos NK, Gorgoulis VG and Kletsas D: Ionizing radiation-mediated premature senescence and paracrine interactions with cancer cells enhance the expression of syndecan 1 in human breast stromal fibroblasts: The role of TGF- $\beta$. Aging (Albany NY) 8: 1650-1668, 2016.

35. Hernandez-Segura A, de Jong TV, Melov S, Guryev V, Campisi J and Demaria M: Unmasking transcriptional heterogeneity in senescent cells. Curr Biol 27: 2652-2660.e4, 2017.

36. Ortiz-Montero P, Londoño-Vallejo A and Vernot JP: Senescence-associated IL- 6 and IL- 8 cytokines induce a self- and cross-reinforced senescence/inflammatory milieu strengthening tumorigenic capabilities in the MCF-7 breast cancer cell line. Cell Commun Signal 15: 17, 2017.

37. Johnston CJ, Hernady E, Reed C, Thurston SW, Finkelstein JN and Williams JP: Early alterations in cytokine expression in adult compared to developing lung in mice after radiation exposure. Radiat Res 173: 522-535, 2010 
38. Papadopoulou A and Kletsas D: Human lung fibroblasts prematurely senescent after exposure to ionizing radiation enhance the growth of malignant lung epithelial cells in vitro and in vivo. Int J Oncol 39: 989-999, 2011.

39. Liao EC, Hsu YT, Chuah QY, Lee YJ, Hu JY, Huang TC, Yang PM and Chiu SJ: Radiation induces senescence and a bystander effect through metabolic alterations. Cell Death Dis 5: e1255, 2014.

40. Sugrue MM, Shin DY, Lee SW and Aaronson SA: Wild-type p53 triggers a rapid senescence program in human tumor cells lacking functional p53. Proc Natl Acad Sci USA 94: 9648-9653, 1997.

41. Beauséjour CM, Krtolica AF, Galimi F, Narita M, Lowe SW, Yaswen P and Campisi J: Reversal of human cellular senescence: Roles of the p53 and p16 pathways. EMBO J 22: 4212-4222, 2014

42. Cheng Z, Zheng YZ, Li YQ and Wong CS: Cellular senescence in mouse hippocampus after irradiation and the role of p53 and p21. J Neuropathol Exp Neurol 76: 260-269, 2017.

43. Widel M, Lalik A, Krzywon A, Poleszczuk J, Fujarewicz K and Rzeszowska-Wolny J: The different radiation response and radiation-induced bystander effects in colorectal carcinoma cells differing in p53 status. Mutat Res 778: 61-70, 2015.

44. Lindgren T, Stigbrand T, Råberg A, Riklund K, Johansson L and Eriksson D: Genome wide expression analysis of radiation-induced DNA damage responses in isogenic HCT116 p53+/+ and HCT116 p53-/- colorectal carcinoma cell lines. Int J Radiat Biol 91: 99-111, 2015.

45. Gong L, Gong H, Pan X, Chang C, Ou Z, Ye S, Yin L, Yang L, Tao T, Zhang Z, et al: p53 isoform $\Delta 113 \mathrm{p} 53 / \Delta 133 \mathrm{p} 53$ promotes DNA double-strand break repair to protect cell from death and senescence in response to DNA damage. Cell Res 25: 351-369, 2015.

46. Sanada F, Taniyama Y, Muratsu J, Otsu R, Iwabayashi M, Carracedo M, Rakugi H and Morishita R: Activated factor X induces endothelial cell senescence through IGFBP-5. Sci Rep 6 : 35580, 2016.

47. Sanada F, Taniyama Y, Muratsu J, Otsu R, Shimizu H, Rakugi H and Morishita R: IGF binding protein-5 induces cell senescence. Front Endocrinol (Lausanne) 9: 53, 2018

48. Kim K, Seu Y, Baek S, Kim MJ, Kim KJ, Kim JH and Kim JR Induction of cellular senescence by insulin-like growth factor binding protein-5 through a p53-dependent mechanism. Mol Biol Cell 18: 4543-4552, 2007.

49. Rombouts C, Aerts A, Quintens R, Baselet B, El-Saghire H, Harms-Ringdahl M, Haghdoost S, Janssen A, Michaux A, Yentrapalli $\mathrm{R}$, et al: Transcriptomic profiling suggests a role for IGFBP5 in premature senescence of endothelial cells after chronic low dose rate irradiation. Int J Radiat Biol 90: 560-574, 2014.

50. Shi W, Tang MK, Yao Y, Tang C, Chui YL and Lee KK: BRE plays an essential role in preventing replicative and DNA damage-induced premature senescence. Sci Rep 6: 23506, 2016.

51. Lukášová E, Kovařík A, Bačíková A, Falk M and Kozubek S Loss of lamin B receptor is necessary to induce cellular senescence. Biochem J 474: 281-300, 2017.

52. Freund A, Laberge RM, Demaria M and Campisi J: Lamin B1 loss is a senescence-associated biomarker. Mol Biol Cell 23: 2066-2075, 2012.

53. Toillon RA, Magné N, Laïos I, Castadot P, Kinnaert E, Van Houtte P, Desmedt C, Leclercq G and Lacroix M: Estrogens decrease gamma-ray-induced senescence and maintain cell cycle progression in breast cancer cells independently of p53. Int J Radiat Oncol Biol Phys 67: 1187-1200, 2007.

54. Abdelmohsen K, Panda A, Kang MJ, Xu J, Selimyan R, Yoon JH, Martindale JL, De S, Wood WH III, Becker KG and Gorospe M: Senescence-associated lncRNAs: Senescence-associated long noncoding RNAs. Aging Cell 12: 890-900, 2013.

55. Sohn D, Peters D, Piekorz RP, Budach W and Jänicke RU: miR-30e controls DNA damage-induced stress responses by modulating expression of the CDK inhibitor p21WAF1/CIP1 and caspase-3. Oncotarget 7: 15915-15929, 2016.

56. Velegzhaninov IO, Ermakova AV and Klokov DY: Low dose ionizing irradiation suppresses cellular senescence in normal human fibroblasts. Int J Radiat Biol 94: 825-828, 2018.

57. Dolan DW, Zupanic A, Nelson G, Hall P, Miwa S, Kirkwood TB and Shanley DP: Integrated stochastic model of DNA damage repair by non-homologous end joining and p53/p21-mediated early senescence signalling. PLoS Comput Biol 11: e1004246, 2015 .
58. Celià-Terrassa T, Liu DD, Choudhury A, Hang X, Wei Y, Zamalloa J, Alfaro-Aco R, Chakrabarti R, Jiang YZ, Koh BI, et al: Normal and cancerous mammary stem cells evade interferon-induced constraint through the miR-199a-LCOR axis. Nat Cell Biol 19: 711-723, 2017.

59. Bai X, Fisher DE and Flaherty KT: Cell-state dynamics and therapeutic resistance in melanoma from the perspective of MITF and IFN $\gamma$ pathways. Nat Rev Clin Oncol: Apr 9, 2019 (Epub ahead of print) Doi: 10.1038/s41571-019-0204-6.

60. Braumüller, H, Wieder T, Brenner E, Aßmann S, Hahn M, Alkhaled M, Schilbach K, Essmann F, Kneilling M, Griessinger C, et al: T-helper-1-cell cytokines drive cancer into senescence. Nature 494: 361-365, 2013.

61. Sato K, Kato A, Sekai M, Hamazaki Y and Minato N: Physiologic thymic involution underlies age-dependent accumulation of senescence-associated CD4(+) T cells. J Immunol 199: 138-148, 2017.

62. Lord CJ and Ashworth A: PARP inhibitors: Synthetic lethality in the clinic. Science 355: 1152-1158, 2017.

63. Efimova EV, Mauceri HJ, Golden DW, Labay E, Bindokas VP, Darga TE, Chakraborty C, Barreto-Andrade JC, Crawley C, Sutton HG, et al: Poly(ADP-ribose) polymerase inhibitor induces accelerated senescence in irradiated breast cancer cells and tumors. Cancer Res 70: 6277-6282, 2010.

64. Barreto-Andrade JC, Efimova EV, Mauceri HJ, Beckett MA, Sutton HG, Darga TE, Vokes EE, Posner MC, Kron SJ and Weichselbaum RR: Response of human prostate cancer cells and tumors to combining PARP inhibition with ionizing radiati on. Mol Cancer Ther 10: 1185-1193, 2011.

65. Chatterjee P, Choudhary GS, Sharma A, Singh K, Heston WD Ciezki J, Klein EA and Almasan A: PARP inhibition sensitizes to low dose-rate radiation TMPRSS2-ERG fusion gene-expressing and PTEN-def icient prostate cancer cells. PLoS One 8: e60408, 2013.

66. Azad A, Bukczynska P, Jackson S, Haupt Y, Cullinane C, McArthur GA and Solomon B: Co-targeting deoxyribonucleic acid-dependent protein kinase and poly(adenosine diphosphate-ribose) polymerase-1 promotes accelerated senescence of irradiated cancer cells. Int J Radiat Oncol Biol Phys 88: 385-394, 2014.

67. Cao F, Ju X, Chen D, Jiang L, Zhu X, Qing S, Fang F, Shen Y, Jia Z and Zhang H: Phosphorothioatemodified antisense oligonucleotides against human telomerase reverse transcriptase sensitize cancer cells to radiotherapy. Mol Med Rep 16: 2089-2094, 2017

68. Orun O, Tiber PM and Serakinci N: Partial knockdown of TRF2 increase radiosensitivity of human mesenchymal stem cells. Int J Biol Macromol 90: 53-58, 2016.

69. Nam HY, Han MW, Chang HW, Kim SY and Kim SW: Prolonged autophagy by MTOR inhibitor leads radioresistant cancer cells into senescence. Autophagy 9: 1631-1632, 2013.

70. Marampon F, Megiorni F, Camero S, Crescioli C, McDowell HP Sferra R, Vetuschi A, Pompili S, Ventura L, De Felice F, et al: HDAC4 and HDAC6 sustain DNA double strand break repair and stem-like phenotype by promoting radioresistance in glioblastoma cells. Cancer Lett 397: 1-11, 2017.

71. Pérès EA, Gérault AN, Samuel V, Roussel S, Toutain J, Divoux D, Guillamo JS, Sanson M, Bernaudin M and Petit E: Silencing erythropoietin receptor on glioma cells reinforces efficacy of temozolomide and X-rays through senescence and mitotic catastrophe. Oncotarget 6: 2101-2119, 2015.

72. Ham SW, Jeon HY and Kim H: Verapamil augments carmustineand irradiation-induced senescence in glioma cells by reducing intracellular reactive oxygen species and calcium ion levels. Tumour Biol 39: 1010428317692244, 2017.

73. Wang M, Morsbach F, Sander D, Gheorghiu L, Nanda A, Benes C, Kriegs M, Krause M, Dikomey E, Baumann M, et al: EGF receptor inhibition radiosensitizes NSCLC cells by inducing senescence in cells sustaining DNA double-strand breaks. Cancer Res 71: 6261-6269, 2011.

74. Mirzayans R, Andrais B and Murray D: Impact of premature senescence on radiosensitivity measured by high throughput cell-based assays. Int J Mol Sci 18: E1460, 2017.

75. Francica P, Aebersold DM and Medova M: Senescence as biologic endpoint following pharmacological targeting of receptor tyrosine kinases in cancer. Biochem Pharmacol 126: 1-12, 2017.

76. Miao GY, Zhou X, Zhang X, Xie Y, Sun C, Liu Y, Gan L and Zhang H: Telomere-mitochondrion links contribute to induction of senescence in MCF-7 cells after carbon-ion irradiation. Asian Pac J Cancer Prev 17: 1993-1998, 2016. 
77. Ernst A, Anders H, Kapfhammer H, Orth M, Hennel R, Seidl K, Winssinger N, Belka C, Unkel S and Lauber K: HSP90 inhibition as a means of radiosensitizing resistant, aggressive soft tissue sarcomas. Cancer Lett 365: 211-222, 2015.

78. Li P, Hou M, Lou F, Björkholm M and Xu D: Telomere dysfunction induced by chemotherapeutic agents and radiation in normal human cells. Int J Biochem Cell Biol 44: 1531-1540, 2012.

79. Maeda T, Nakamura K, Atsumi K, Hirakawa M, Ueda Y and Makino N: Radiation-associated changes in the length of telomeres in peripheral leukocytes from inpatients with cancer. Int J Radiat Biol 89: 106-109, 2013.

80. Jinno-Oue A, Shimizu N, Hamada N, Wada S, Tanaka A, Shinagawa M, Ohtsuki T, Mori T, Saha MN, Hoque AS, et al: Irradiation with carbon ion beams induces apoptosis, autophagy, and cellular senescence in a human glioma-derived cell line. Int J Radiat Oncol Biol Phys 76: 229-241, 2010.

81. Pan J, Li D, Xu Y, Zhang J, Wang Y, Chen M, Lin S, Huang L, Chung EJ, Citrin DE, et al: Inhibition of Bcl-2/xl with ABT-263 selectively kills senescent type II pneumocytes and reverses persistent pulmonary fibrosis induced by ionizing radiation in mice. Int J Radiat Oncol Biol Phys 99: 353-361, 2017.

82. Chung EJ, McKay-Corkum G, Chung S, White A, Scroggins BT, Mitchell JB, Mulligan-Kehoe MJ and Citrin D: Truncated plasminogen activator inhibitor-1 protein protects from pulmonary fibrosis mediated by irradiation in a murine model. Int $\mathbf{J}$ Radiat Oncol Biol Phys 94: 1163-1172, 2016.

83. Chung EJ, Sowers A, Thetford A, McKay-Corkum G, Chung SI, Mitchell JB and Citrin DE: Mammalian target of rapamycin inhibition with rapamycin mitigates radiation-induced pulmonary fibrosis in a murine model. Int J Radiat Oncol Biol Phys 96: 857-866, 2016.

84. Shao L, Feng W, Li H, Gardner D, Luo Y, Wang Y, Liu L, Meng A, Sharpless NE and Zhou D: Total body irradiation causes long-term mouse BM injury via induction of HSC premature senescence in an Ink4a- and Arf-independent manner. Blood 123: 3105-3115, 2014.

85. Chang J, Wang Y, Shao L, Laberge RM, Demaria M, Campisi J, Janakiraman K, Sharpless NE, Ding S, Feng W, et al: Clearance of senescent cells by ABT263 rejuvenates aged hematopoietic stem cells in mice. Nat Med 22: 78-83, 2016.

86. Lu L, Wang YY, Zhang JL, Li DG and Meng AM: p38 MAPK inhibitor insufficiently attenuates HSC senescence administered long-term after 6 Gy total body irradiation in mice. Int J Mol Sci 17: E905, 2016.

87. Ness KK, Armstrong GT, Kundu M, Wilson CL, Tchkonia T and Kirkland JL: Frailty in childhood cancer survivors. Cancer 121: $1540-1547,2015$.

88. Ariffin H, Azanan MS, Abd Ghafar SS, Oh L, Lau KH, Thirunavakarasu T, Sedan A, Ibrahim K, Chan A, Chin TF, et al: Young adult survivors of childhood acute lymphoblastic leukemia show evidence of chronic inflammation and cellular aging. Cancer 123: 4207-4214, 2017.

89. Artoni F, Kreipke RE, Palmeira O, Dixon C, Goldberg Z and Ruohola-Baker H: Loss of foxo rescues stem cell aging in Drosophila germ line. eLife 6: e27842, 2017.

90. Alessio N, Capasso S, Di Bernardo G, Cappabianca S, Casale F Calarco A, Cipollaro M, Peluso G and Galderisi U: Mesenchyma stromal cells having inactivated RB1 survive following low irradiation and accumulate damaged DNA: Hints for side effects following radiotherapy. Cell Cycle 16: 251-258, 2017.

91. Xing Y, Zhang J, Lu L, Li D, Wang Y, Huang S, Li C, Zhang Z, Li J and Meng A: Identification of hub genes of pneumocyte senescence induced by thoracic irradiation using weighted gene coexpression network analysis. Mol Med Rep 13: 107-116, 2016.

92. Alessio N, Esposito G, Galano G, De Rosa R, Anello P, Peluso G, Tabocchini MA and Galderisi U: Irradiation of mesenchymal stromal cells with low and high doses of alpha particles induces senescence and/or apoptosis. J Cell Biochem 118: 2993-3002, 2017

93. Ramos Silva C, Cabral FV, de Camargo CF, Núñez SC, Mateus Yoshimura T, de Lima Luna AC, Maria DA and Ribeiro MS: Exploring the effects of low-level laser therapy on fibroblasts and tumor cells following gamma radiation exposure. J Biophotonics 9: 1157-1166, 2016.

94. Hamdi DH, Chevalier F, Groetz JE, Durantel F, Thuret JY, Mann C and Saintigny Y: Comparable senescence induction in three-dimensional human cartilage model by exposure to therapeutic doses of x-rays or C-ions. Int J Radiat Oncol Biol Phys 95: 139-146, 2016.

95. Baker DJ, Wijshake T, Tchkonia T, LeBrasseur NK, Childs BG van de Sluis B, Kirkland JL and van Deursen JM: Clearance of p16Ink4a-positive senescent cells delays ageing-associated disorders. Nature 479: 232-236, 2011
96. Kosmacek EA, Chatterjee A, Tong Q, Lin C and OberleyDeegan RE: MnTnBuOE-2-PyP protects normal colorectal fibroblasts from radiation damage and simultaneously enhances radio/chemotherapeutic killing of colorectal cancer cells. Oncotarget 7: 34532-34545, 2016.

97. Beach TA, Johnston CJ, Groves AM, Williams JP and Finkelstein JN: Radiation induced pulmonary fibrosis as a model of progressive fibrosis: Contributions of DNA damage, inflammatory response and cellular senescence genes. Exp Lung Res 43: 134-149, 2017.

98. Philipp J, Azimzadeh O, Subramanian V, Merl-Pham J, Lowe D, Hladik D, Erbeldinger N, Ktitareva S, Fournier C, Atkinson MJ, et al: Radiation-induced endothelial inflammation is transferred via the secretome to recipient cells in a STAT-mediated process. J Proteome Res 16: 3903-3916, 2017.

99. Chatterjee A, KosmacekEA and Oberley-Deegan RE: MnTE-2-PyP treatment, or NOX4 inhibition, protects against radiation-induced damage in mouse primary prostate fibroblasts by inhibiting the TGF-Beta 1 signaling pathway. Radiat Res 187: 367-381, 2017.

100. Li H, Wang Y, Pazhanisamy SK, Shao L, Batinic-Haberle I, Meng A and Zhou D: Mn(III) meso-tetrakis-(N-ethylpyridinium-2-yl) porphyrin mitigates total body irradiation-induced long-term bone marrow suppression. Free Radic Biol Med 51: 30-37, 2011.

101. Xu G, Wu H, Zhang J, Li D, Wang Y, Wang Y, Zhang H, Lu L, Li C, Huang S, et al: Metformin ameliorates ionizing irradiation-induced long-term hematopoietic stem cell injury in mice. Free Radic Biol Med 87: 15-25, 2015.

102. Kaur E, Rajendra J, Jadhav S, Shridhar E, Goda JS, Moiyadi A and Dutt S: Radiation-induced homotypic cell fusions of innately resistant glioblastoma cells mediate their sustained survival and recurrence. Carcinogenesis 36: 685-695, 2015.

103. Roberson RS, Kussick SJ, Vallieres E, Chen SY and Wu DY: Escape from therapy-induced accelerated cellular senescence in p53-null lung cancer cells and in huma n lung cancers. Cancer Res 65: 2795-2803, 2005

104. Chakradeo S, Elmore LW and Gewirtz DA: Is senescence reversible? Curr Drug Targets 17: 460-466, 2016.

105. Tato-Costa J, Casimiro S, Pacheco T, Pires R, Fernandes A, Alho I, Pereira P, Costa P, Castelo HB, Ferreira J and Costa L: Therapy-induced cellular senescence induces epithelial-to-mesenchymal transition and increases invasiveness in rectal cancer. Clin Colorectal Cancer 15: 170-178 e3, 2016.

106. Gewirtz DA, Alotaibi M, Yakovlev VA and Povirk LF: Tumor cell recovery from senescence induced by radiation with PARP inhibition. Radiat Res 186: 327-332, 2016.

107. Alotaibi M, Sharma K, Saleh T, Povirk LF, Hendrickson EA and Gewirtz DA: Radiosensitization by PARP inhibition in DNA repair proficient and deficient tumor cells: Proliferative recovery in senescent cells. Radiat Res 185: 229-245, 2016.

108. Hellevik T, Pettersen I, Berg V, Winberg JO, Moe BT, Bartnes K, Paulssen RH, Busund LT, Bremnes R, Chalmers A and Martinez-Zubiaurre I: Cancer-associated fibroblasts from human NSCLC survive ablative doses of radiation but their invasive capacity is reduced. Radiat Oncol 7: 59, 2012.

109. Frame FM, Savoie H, Bryden F, Giuntini F, Mann VM, Simms MS, Boyle RW and Maitland NJ: Mechanisms of growth inhibition of primary prostate epithelial cells following gamma irradiation or photodynamic therapy include senescence, necrosis, and autophagy, but not apoptosis. Cancer Med 5: 61-73, 2016.

110. Malaquin N, Martinez A and Rodier F: Keeping the senescence secretome under control: Molecular reins on the senescence-associated secretory phenotype. Exp Gerontol 82: $39-49,2016$

111. Wiley CD and Campisi J: From ancient pathways to aging cells-connecting metabolism and cellular senescence. Cell Metab 23: 1013-1021, 2016.

112. Rodier F and Campisi J: Four faces of cellular senescence. J Cell Biol 192: 547-556, 2011.

113. Rzeszowska-Wolnyab J and Widel M: Ionizing radiation-induced bystander effects, potential targets for modulation of radiotherapy. Eur J Pharmacol 625: 156-164, 2009.

114. Jalal N, Haq S, Anwar N, Nazeer S and Saeed U: Radiation induced bystander effect and DNA damage. J Cancer Res Ther 10: 819-833, 2014

115. Özcan S, Alessio N, Acar MB, Mert E, Omerli F, Peluso G and Galderisi U: Unbiased analysis of senescence associated secretory phenotype (SASP) to identify common components following different genotoxic stresses. Aging (Albany NY) 8: 1316-1329, 2016. 
116. Mowla SN, Lam EW and Jat PS: Cellular senescence and aging: The role of B-MYB. Aging Cell 13: 773-779, 2014.

117. Jin X, Li F, Liu B, Zheng X, Li H, Ye F, Chen W and Li Q Different mitochondrial fragmentation after irradiation with $\mathrm{X}$-rays and carbon ions in HeLa cells and its influence on cellular apoptosis. Biochem Biophys Res Commun 500: 958-965, 2018.

118. Capasso S, Alessio N, Squillaro T, Di Bernardo G, Melone MA, Cipollaro M, Peluso G and Galderisi U: Changes in autophagy, proteasome activity and metabolism to determine a specific signature for acute and chronic senescent mesenchymal stromal cells. Oncotarget 6: 39457-39468, 2015.

119. Ziegler DV, Wiley CD and Velarde MC: Mitochondrial effectors of cellular senescence: Beyond the free radical theory of aging. Aging Cell 14: 1-7, 2015.

120. Lafargue A, Degorre C, Corre I, Alves-Guerra MC, Gaugler MH, Vallette F, Pecqueur $\mathrm{C}$ and Paris F: Ionizing radiation induces long-term senescence in endothelial cells through mitochondrial respiratory complex II dysfunction and superoxide generation. Free Radic Biol Med 108: 750-759, 2017.

121. Masaldan S, Clatworthy SAS, Gamell C, Meggyesy PM, Rigopoulos AT, Haupt S, Haupt Y, Denoyer D, Adlard PA, Bush AI and Cater MA: Iron accumulation in senescent cells is coupled with impaired ferritinophagy and inhibition of ferroptosis. Redox Biol 14: 100-115, 2018.
122. Doll S, Proneth B, Tyurina YY, Panzilius E, Kobayashi S, Ingold I, Irmler M, Beckers J, Aichler M, Walch A, et al: ACSL4 dictates ferroptosis sensitivity by shaping cellular lipid composition. Nat Chem Biol 13: 91-98, 2017.

123. Li T and Chen ZJ: The cGAS-cGAMP-STING pathway connects DNA damage to inflammation, senescence, and cancer. J Exp Med 215: 1287-1299, 2018.

124. Yang H, Wang H, Ren J, Chen Q and Chen ZJ: cGAS is essential for cellular senescence. Proc Natl Acad Sci USA 114: E4612-E4620, 2017.

125. Glück S, Guey B, Gulen MF, Wolter K, Kang TW, Schmacke NA, Bridgeman A, Rehwinkel J, Zender L and Ablasser A: Innate immune sensing of cytosolic chromatin fragments through cGAS promotes senescence. Nat Cell Biol 19: 1061-1070, 2017

126. Sun Y, Coppé JP and Lam EW: Cellular senescence: The sought or the unwanted? Trends Mol Med 24: 871-885, 2018.

127. Leite de Oliveira R and Bernards R: Anti-cancer therapy: Senescence is the new black. EMBO J 37: e99386, 2018. 